\title{
The Relationship between Students' Perceived Needs, Their Learning Preferences, and Their Ability of Writing an Academic Text
}

\author{
Yenni Rozimela $^{1^{*}}$, Delvi Wahyuni ${ }^{2}$ \\ Faculty of Languages and Arts, Universitas Negeri Padang, Indonesia
}

*Corresponding Author: Yenni Rozimela, Faculty of Languages and Arts, Universitas Negeri Padang, Indonesia

\begin{abstract}
This article presents a study investigating a relation between students' perceived of writing, their learning preferences, and their writing ability. The study was conducted prior to the development a cognitivegenre-based model of teaching academic writing to EFL students. The population was 105 students who had taken three prerequisite writing subjects. The data were collected through questionnaire and writing test. The questionnaires were distributed to all of the students to find out their perceived needs and their learning prefenrences. The test was given to thirty randomly selected students in order to see their writing ability. The students were required to write 2 different academic genres, a discussion and a report text. The result of the the first questionnaire analysis reveals that the students thought that they had fairly good knowledge about developing an academic text. Based on the second questionnaire it was found that the students tended to be dependent on teachers. The students' writings, however, indicated that the students had various factors problems in developing and organizing their ideas even though their texts contained the components of the generic structure. Furthermore, they had complex lexico grammar problems. Based on these results it can be concluded that there was a gap between the students' perceived needs, their learning preferences, and their writing ability. A model of teaching academic texts which gives attention to both discourse and language aspects.
\end{abstract}

\section{INTRODUCTION}

EFL learners, especially those majoring in English Education are expected to write well in order to pass some academic requirements such writing term-papers or undergraduate thesis. However, it is a widely known that academic writing is by no means an easy feat. In this regard, writing as a language skill, compared to speaking, reading and listening, is considered as the most difficult one to master by L2 learners [1], [2], [3], [4], [5], [6]. EFL learners have to deal with an "extra cognitive burden" when it comes to academic writing [7]. By nature, writing is indeed a very complex activity because it involves both cognitive and affective process [8], [9], [10]. Moreover, it is explained that L2 writing is difficult because L2 learners have to employ multitudes of skills such as planning, organizing, spelling, punctuation, word choice, to name a few [11]. Therefore, it is not surprising if some studies have found out that EFL learners studying at tertiary level are wary of activities involving writing to the extent of avoiding writing altogether [12], [13]. $\mathrm{f}$ the do write, as what happens in the context of this study, students come up with poorly written piece which does not reflect the years they have spent to study English and the craft of writing academically in English. Thus, there is a need to conduct a research on students' need of an effective teaching model to sort the aforementioned problem.

Numerous studies have pointed out that the culprit is commonly associated with students' difficulties with in EFL writing is weak linguistic competence with grammatical ability topping other debilitating linguistic factors [14], [3], [15], [4]. Despite no definitive conclusions about the apposition of grammatical ability and writing ability [2], preliminary observation showed that students with poor grammatical ability struggled in any writing classes they took.. Another underlying factor which might contribute to the problem of EFL writing is the fact that writing is not merely about putting together error free sentences but also the appropriateness of using the structure and the language specific of a genre to communicate the idea the writers want to share. 
A current approach aiming at equipping students with genre awareness to ensure their success in both academic and professional situation is the Genre-Based Approach [16], [17], [18], [19]. According to this approach, students must be introduced to core components of texts/genres which include social function, generic structure, and linguistic features. Research conducted to EFL learners in Indonesia, site of this current approach [20], [21], [22], [23] generally show promising results. In spite of that, findings and discussions of the studies indicate that to some extent problems dealing with language use persist.

A Cognitive Approach to Grammar Instruction using an information processing model by [24] which develops grammatical knowledge and promotes its acquisition through communicative activities is assumed to help students with grammar problems in writing. A study, for instance, shows that Cognitive Approach applied in a TOEFL preparation class had a better effect on the participants' grammar achievement [25]. Thus, weaving the principles of the Cognitive Approach into the GenreBased Approach is assumed to be able to cater for a need of students with poor grammar, yet are demanded to produce good academic writing.

To design an appropriate model, an analysis of students' needs is important. Needs refers to necessities, lacks, and wants [26]. It is argued that what learners perceive as their needs (subjective needs) and their preferences about how to learn writing. What learners think as their needs can reflect their lacks and necessities teachers have to consider in their teaching plan. Need is viewed from two sides, what students perceived what they need and what they need judged from their writing. Preferences of teaching strategies/techniques which may reflect their learning styles can be considered as learners' wants. In order to have a model of teaching model that suits the learners, needs analysis is needed.

This article presents the result of a study looking at these two sides of needs and their relationship prior to designing a model of teaching writing using a Cognitive Genre-Based Approach. The first kind of needs dealt what the students thought as their necessities and wants of learning writing including grammar and their preferences of learning writing. The second one was their actual needs reflected in their writing.

\section{RESEARCH METHOD}

This descriptive study was aimed to look at the relationship between the students' perceived needs and their writing ability in order to develop a model of teaching academic texts. The population was 105 students who had taken three prerequisite writing subjects.

The data were collected through two sets of questionnaires and a writing test. The first one was intended to find out the students' perception on their writing ability. This consisted of two parts, ability of general writing and writing of genre specific. The questionnaires were developed based on the indicators of academic writing components that can be divided into three main groups, idea development, organization, and language use and the indicators of the generic structure and the lexico grammar features of the two genres they were required to write in the writing test (i.e. Discussion and Report texts). The second one was concerned with students' learning preferences. The questions were developed on alternative ways of learning the generic structure and the lexicogrammar features of the concerning texts. To find out the students' writing ability, a writing test requiring the students to write two different academic genres, discussion and factual report, was administered. The instruments could be sidered valid because the students had taken an academic writing subject whereby the learned how to write several academeic genres including Discussion and Report texts. To increase the validity of the instruments, an experienced writing lecturer was required to validate them.

The data were collected at two different times. The first one was at the beginning of the course to distribute the questionnaires about students' perception of their writing ability. The second one was at the end of the course to find out their writing ability through a writing test. Both were done in class.

The data were analyzed quantitatively and qualitatively. The students were to decide their needs of each item in the questionnaire in a scale of 1-5. The average percentage of the each group of questions was gained through a process of a simple statistical analysis. The students' answers in the questionnaire were classified and calculated to draw average percentage of each classification. The texts were scrutinized to show the students' ability in writing. Each text was analyzed based on the 
predetermined indicators. Then, the results of the analysis of the questionnaires and the texts produced by the students were compared to explain the extent to which the students' perceived needs were related with their writing ability.

\section{FindingS}

The results of data analysis were grouped into the students' perceived needs, their learning preferences, and their needs reflected in their writing ability. The average percentage of the students' answers of the questionnaires was classified on the basis of grand mean percentage, which is: very good (100-81), good (80-61), sufficient (60-41), poor (40-21), and very poor (20-0). Based on the the results of the analysis, it is found that that the relationship between their perceived needs, their writing ability, and learning preferences was arbitrary. The following sections present the details of the findings.

\subsection{Students' Perceived Needs}

The students' perceived needs were gathered and interpreted from what they thought they had and had not understood about academic writing in general, about writing different types of genres, and use of lexicogrammar of the corresponding genres in the questionnaire. Their perceived needs were also obtained from how they thought they had tobe taught in writing and their learning preferences. Generally the students thought they had good understanding about how to write English academic texts even though their answers to some extent indicate that they were of their lacks. Their writing problems regarding grammar especially, as reflected in their writing were away bigger than their claim. Their answers about their understanding of grammar in general did not correspond with that of grammar of specific genres. In other words, there was also a gap between their knowledge about grammar and their ability to use that knowledge in writing. The students tended to answer that they knew the lexicogrammar items raised in the questionnaire, while their writing did not show such such understanding. Then, the result of the students' learning preferences analysis reveals that the students preferred intensive guidance from teachers. They tended not to choose statements related to independent learning such as searching for uninstructed sources and self-revision.

\subsection{Needs of General Academic Writing}

There were 28 questions regarding students' perceived needs about general writing. The questions covered three main groups: 1) understanding of how to formulate and develop ideas, 2) understanding how to organize ideas, and 3) understanding of dominant lexicogrammar features of academic genres.

It was found that the students asserted that they had fairly good understanding of how to write an academic text. In fact, the students thought they understood how to determine a topic $(90 \%)$, to narrow down a topic (81\%), and develop an introduction (81\%), body paragraphs (78\%), and conclusion (90\%). This means that they thought either they had good or sufficient knowledge to determine to develop ideas in writing.

They also thought that they had fairly good understanding how to sturture a text $(80 \%)$, to relate paragraphs $(84 \%)$, and relate one sentence with another $(80 \%)$. This means that they believed that were able to structure their writing, to arrange paragraphs, and to arrange sentences.

There questions dealing with lexicogrammar were developed based on common features of academic texts and the major common mistakes made by the students. It was found that the students' understanding of lexicogrammar was rather low, tenses $80 \%$, clause complexes $60 \%$, passive construction $73 \%$, modality $60 \%$, cohesive devices $60 \%$, subject verb agreement $80 \%$, articles $51 \%$, diction $60 \%$, and technical terms $47 \%$ ). The students This means that their answers were either sufficient or poor.These figures indicate that the students were aware of their limited knowledge and skills at some points of the three aspects raised in the questionnaire. Besides that they apparently believed that their knowledge of grammar was not as good as their skills of how to develop and organize ideas in writing.

The results imply that the students thought that they did not think that their needs of knowledge about how to develop and organize ideas were not that high as they claimed they had relatively good knowledge and skills of writing. Yet, they thought they needed knowledge about lexicogrammar as reflected in their limited understanding on this aspect. 


\subsection{Needs of Writing of Academic Genres}

There were 40 questions about two selected academic genres, Discussion and Report. The questions were intended to find out the students' understanding about these genres. Sixteen questions were concerned with the generic structure and twenty questions were about lexicogrammar. Their answeres revealed that their understanding was moderate and was fairly similar for both genres.

As for discussion text, knowledge about the generic structure reached the highest percentage $(74 \%)$. The students also claimed that they had sufficient ability to write and develop arguments (70\%), write arguments from different points of view (69\%), and recommendation (67\%). This means that they students perceived that they had fairly good ability to write a discussion text. In spite of that, the average percentage of each aspect indicates that some students were aware of their limited understanding at some points (around 30\%).

The students' answers dealing with report text reveal the same result. Their understanding of the generic structure of this genre was $72 \%$. They thought they could write a general classification (72\%) and could describe the characteristics of the thing to be reported (73\%). Similar to their perceived needs of writing a discussion text, the students understood that they had limited ability in a few aspects of the genre.

Next, there were 24 questions about dominant grammar features of the concerning academic genres. Generally the students thought they had good understanding about the lexicogrammar features. The average percentage of students' understanding of the grammar points for nouns was $84 \%$, tenses $79 \%$, conjunctions and transitions $75 \%$, evaluative language $63 \%$, diction $60 \%$, and technical terms $58 \%$. These figures show that the students thought that their knowledge on grammar was better than lexis.

Thus, it could be concluded that the students thought they had adequate knowledge and skills to write discussion and report texts. Still, the students apparently felt that their lexicogrammar knowledge was insufficient. This means that the students needed lessons on lexicogrammar.

\subsection{Needs of Learning Academic Writing}

The students' preferences of learning writing were considered important in order to suit the designed model with the students' characteristics of learning. There were questions -20 questions concerning this aspect that could be grouped into three main tendencies; they were questions 1) reflecting dependent learning, 2) collobarative/ cooperative learning, and 3) independent learning.

The highest percentage (97\%) dealt with questions of lecturers' explanation of the generic structure of a genre and the text models. For example, many students chose 'absolutely agree' with the statement the lecturer explains the generic characteristics of a text and the lecturer reviews the dominant grammar of a text. This means that the students wanted their lecturers give explanation (lecture) on these two components. The lowest percentage (34\%) dealt with items of independent learning such as the lecture requires you to search for related references to support their ideas and to do self-editing. Meanwhile, the average percentage of questions pertaining collaborative /cooperative learning was moderate $(60 \%)$.

The students' answers about the preferences of learning writing reveal their dependency on lecturers. In fact, they preferred teacher- centered activities to student- centered activities. This may disadvantage the students in accelerating their writing progress because they were not autonomous learners.

\subsection{Students' Writing}

The results of the analysis about the students' needs collected through a writing test indicate that the students have not been able to produce good academic texts yet. Even though some of them managed to write understandable texts, many had various discourse and lexicogrammar problems. The results will be described under two main headings, the texts viewed from their generic structure and viewed from their lexicogrammar.

\subsubsection{The Generic Structure of the Students' Texts}

\section{a) Discussion Text}

The topic of the text was working after graduating from high school before continuing to university. The students were required to write a text which discussed the advantages and disadvantages of 
working after high school graduation. The result showed that $90 \%$ of the texts discussed the issue from two points of view. Three of them (10\%), however, argued from one side which revealed the feature of an exposition text. Apparently, these three students misunderstood with the prompt of the question or with the meaning of 'discuss'. Thus, they wrote an exposition text rather than a discussion text.

The first component of the generic structure of a discussion is Statement of Issue through which the writer introduces the issue with the points of view of the forthcoming discussion. Almost all of the students who produced a discussion text $(90 \%)$ wrote the Statement of the Issue, while $10 \%$ wrote a Thesis Statement as they wrote an exposition text. The Statement of Issue should be written in one statement. Two of the students, however, wrote it in 2 statements. Even though this way of writing Statement of Issue is not wrong, it may slow down the readers or may look at the second statement.

The second component is arguments of different views. Twenty five students wrote arguments for and against, but two students only wrote arguments for. It means that the two students supported the Statement of Issue partially. All students wrote the arguments explicitly at the beginning of each paragraph. This means that the students have understood how an argument should be stated in an English discussion text. No student wrote an argument inductively or implicitly. This may be resulted from the models they were introduced to and the explanation given by the lecturer when they learned how to write a discussion text.

Each argument must be supported or elaborated by further explanation and/or provision of relevant facts/evidence and/or examples. Most of the students had problems in this aspect. They relied too much on their personal opinions and feelings. They lacked factual data and examples to support their arguments. In effect, the readers would not get sufficient information. Moreover, the arguments became weak because they were not supported with data or evidence. The students' limited ability to write elaboration of the arguments most likely seems due to their insufficient related background knowledge about the topic. Probably the students did not read enough. If they did (they were required to), they might have reading comprehension problems.

The last component of a discussion is a conclusion which presents a reiteration of the statement of issue and recommendation. All students wrote a conclusion paragraph either by restating the statement of issue with or without recommendations. It can be concluded that the students understood the last component of the generic structure of a discussion text.

\section{b) Factual Report}

For factual report the students were required to write one of the options - animals, plants, or objects. They were encouraged to read some sources, but reminded not to copy-paste any sources. The result of the analysis shows that all students understood the components of the generic structure of a discussion text. Their texts contained general classification and description.

All students began their texts by providing general classification of the topics. Some of them used technical terms they quoted from the references, while the others did not. Most of them wrote 2 sentences, one as introduction and the other as classification sentence. Most of them chose to write animals such as cats and tigers.

The content of the second component, the description, was quite good. In some texts, however, it was too simple. Generally, the students described the physic, the food, and the habit or the quality of the animals. The students who seemed to have lots of reading about the animals wrote had better elaborated description, and vice versa. In addition, they also had better language expressions. Nonetheless, it was also found that there were a few students who took so much from the sources that many sentences sound like plagiarism.

\subsubsection{Lexicogrammar Features}

The result of the analysis shows that the students had various complicated grammar problems in both text types. They also often used inappropriate diction. Furthermore, their grammar problems hindered understanding at times. Their major grammar problems were evident in many aspects, among others: 1) simple and complex sentences, 2) subject-verb agreement, 3) passive voice, 4) plural-singular nouns, 5) modal auxiliary, 6) transitions and conjunctions, and 7) tenses. As the focus of the analysis 
was to get a description of students' lack, the mistakes were not analyzed quantitatively. For these reasons, the mistakes were presented in the following table to show some samples of the sentences produced by different students in which the variety of mistakes appeared.

Table1. Sample of Mistakes

\begin{tabular}{|c|c|c|}
\hline No & Mistakes in both grammar and diction & Samples \\
\hline 1 & $\begin{array}{ll}- & \text { use of those } \\
- & \text { use of it in the second clause }\end{array}$ & $\begin{array}{l}\text { For those students who decide to work } \\
\text { before entering university, it will disturb } \\
\text { their process of learning. }\end{array}$ \\
\hline 2 & $\begin{array}{l}\text { - } \quad \text { the use of 'all' } \\
\text { - } \quad \text { the use of verb be 'are' } \\
\text { - } \quad \text { the diction of 'get' }\end{array}$ & $\begin{array}{l}\text { It is all because there are a gap or free time } \\
\text { for the students until they get their } \\
\text { graduation day. }\end{array}$ \\
\hline 3 & $\begin{array}{l}\text { - the use of verb be 'are' } \\
\text { - the use of singular instead of plural of 'student', thus } \\
\text { also the use of 'does' }\end{array}$ & $\begin{array}{l}\text { Second, the disadvantage of working } \\
\text { before study in university is student does } \\
\text { not have any background knowledge. }\end{array}$ \\
\hline 4 & $\begin{array}{l}\text { - } \quad \text { the use of singular instead plural of 'student' } \\
\text { - the use of conjunction 'and' } \\
\text { - the use of ing in 'learning' } \\
\text { - the of present participle in 'working' } \\
\text { - } \quad \text { the meaning of the whole sentence is vague }\end{array}$ & $\begin{array}{l}\text { The student does not know how to } \\
\text { manage time and they will learn in the } \\
\text { working time. }\end{array}$ \\
\hline 5 & $\begin{array}{l}\text { - the use of 'stress' instead of 'stressful' } \\
\text { - the use of singular instead of plural for 'student' }\end{array}$ & $\begin{array}{l}\text { The student may be stress and do not want } \\
\text { to work anymore. }\end{array}$ \\
\hline 6 & $\begin{array}{l}\text { - } \quad \text { no subject in the first clause } \\
\text { - } \quad \text { The meaning of the whole sentence is vague }\end{array}$ & $\begin{array}{l}\text { Although already following the various } \\
\text { college entrance selection, there are those } \\
\text { who have not managed to enter the majors of } \\
\text { dream lecture. }\end{array}$ \\
\hline 7 & $\begin{array}{l}\text { - } \quad \text { the use of 'as' } \\
\text { - the use passive voice 'can use' instead of 'can be used' } \\
\text { - } \quad \text { the use of preposition 'for' }\end{array}$ & $\begin{array}{l}\text { Money that they get as salary can use to } \\
\text { pay their tuition for university. }\end{array}$ \\
\hline 8 & $\begin{array}{l}\text { - the diction 'directly', 'worries', and 'environment' } \\
\text { - the use of verb be 'is' instead of 'are' }\end{array}$ & $\begin{array}{l}\text { After that, if the students do not directly } \\
\text { continue their study, they will get worries } \\
\text { from the environment especially from their } \\
\text { friends who is already in college. }\end{array}$ \\
\hline 9 & $\begin{array}{l}\text { - the use preposition 'to' } \\
\text { - the use passive voice 'encourage' instead of ' be } \\
\text { encouraged' } \\
\text { - the use of 'year' instead of 'years' } \\
\text { - diction 'identify' }\end{array}$ & $\begin{array}{l}\text { Moreover, before entering to higher } \\
\text { education, young people should encourage } \\
\text { to work or travel for year so they can } \\
\text { identify the real situation }\end{array}$ \\
\hline 10 & $\begin{array}{l}\text { - } \quad \text { the use of 'sometime' instead of 'sometimes' } \\
\text { - } \quad \text { the use of 'many of students' } \\
\text { - } \quad \text { word order of a phrase' they want to take what majors' } \\
\text { - } \quad \text { diction 'mistaken', ' in hurry' } \\
\text { - } \quad \text { The meaning of the whole sentence is awkward. }\end{array}$ & $\begin{array}{l}\text { Sometime many of students do not know } \\
\text { they want to take what majors in college } \\
\text { therefore many students are mistaken for } \\
\text { majors because they are in a hurry to } \\
\text { decide. }\end{array}$ \\
\hline
\end{tabular}

From the samples of the sentences above it can be seen that the students had various grammar problems. Sometimes their mistakes cause confusion. Even though most of the sentences seemed to be understandable for Indonesian readers, native speakers may be confused reading them. Hence, the quality of their writing as a whole could be considered very low. It should be noted that these students had taken four grammar subjects, but their writing reflected their limited understanding of what they had learned.

\section{DISCUSSION AND IMPLICATION}

Some interesting issues emerged in the data obtained through questionnaires answered by the students and their writing. First, that there is a gap students' declarative and the procedural knowledge in idea development and lexicogrammar aspects was reflected in their answers. Generally most of the students (around 70\%) thought they could develop ideas and had knowledge on the most of the writing components. Unfortunately, problems occurred in their writings at times. Second, the students' preferences of learning writing (teacher-centered) seem to one of the factors that explains their writing problems. 
The students' belief on their ability to develop ideas in the questionnaire was not fully supported by their writing. Many arguments were not elaborated well. This could be resulted from their limited background knowledge about the concerning issues. This result is in line with other research [21], [22]. Examples or evidence to support arguments and description of an object of a factual report are largely available in reading texts such as articles and books. It can be inferred that the inadequate elaboration of points in their writing was most likely due to the students' lack of reading. Thus, encouraging students to read various resources, integrating reading activities to the other language skills such as writing, and designing takes which require students to read as reading-based oral report can be alternative solutions to this problem.

Another problem which also reflects students' lack of reading was their vocabulary shortage. Their awareness of their limited range of vocabulary corresponded with their problems in diction and using word variation in their essays. Besides that, they hardly used technical terms dealing with the topics of the essays. This may be due a tendency of neglecting vocabulary teaching. It is noted that most researchers suggest a well-structured vocabulary program that both explicit and incidental learning [27]. Furthermore, Decarrico asserts that a good way to help students cope with vocabulary problems is exposing them to extensive reading.

The students' cognition of grammar in general as reflected in their answers was moderate. In contrast, their writings contained complicated grammar problems. This phenomenon has been an issue at the English department (this research site) for a decade or so. Actually, the students learn grammar in four prerequisite grammar subjects at college (i.e. the site of this study). With such background knowledge, it is expected that they would not face such difficulties in writing an essay. This means there is a gap between the students' declarative and their procedural knowledge on grammar. There could be some reasons behind this fact. First, the students apparently had incomplete understanding of the grammar rules they learned. Second, they probably did not have opportunity to practice the learned rules into practice of using them in authentic communication, which might be because of limited communicative grammar exercises or limited exposure to English use especially written English texts. Focusing students' attention on linguistic form during communicative interactions has revealed better results than giving decontextualized grammar lessons [28]. In line with this, it is stated that meaning-focused and form-focused exercises are necessary for fluency and accuracy in foreign and foreign language learning [24]. Last, most of the students were very much influenced by their Indonesian or even ethnic language. Thus, many language expressions and sentence grammar patterns reflected Indonesian language.

The students' way of learning preferences is also interesting to note. As they tended to choose activities prioritizing lecturer's active role, they could be considered as dependent learners. In other words, they were not autonomous learners. Having autonomy, learners are able to take independent action and reflect upon their learning outcomes [29]. These characteristics apparently were not built up in the students of this current study. They may read sources if they were instructed to do so. They also did not seem do much self-revision and edition. It was reflected in their writings that were short of idea development showing limited readings, and complicated sentence grammar problems indicating their lack of ability to improve their own writing. It is noted that autonomy is a potential capacity that needs to be developed in learners [30]. To develop this capacity, teachers should apply an approach or method empowering learner autonomy.

\section{CONCLusion}

Based on the result of the data analysis showing the students' writing problems, this study has unveiled the students' needs of academic writing. There was a difference between their perceived needs with their real needs reflected in their writing. Their perception may be based on their understanding about how to write (i.e. declarative knowledge). Their writings, however, show that the students need to learn how to elaborate their points. This problem seems to be rooted from their limited readings, and it is also probably because of their reading comprehension problems. Furthermore, their complex lexicogrammar mistakes indicate that they had not understood and not been able to apply their grammar knowledge they had learned grammar in three subjects. These results imply a need to improve the process of teaching and learning which addresses both discourse and lexicogrammar of a text. Explicit teaching and extra emphasis and grammar use in context should 
be given. To meet such needs, a model of teaching writing which puts balanced emphasis on discourse and language skill development is needed.

\section{REFERENCES}

[1] Lee, S. (2005). Facilitating and inhibiting factors in English as a foreign language writing performance: a model testing with structural equation modeling. Language Learning. 5 (2): 335-374.

[2] Dai, F. (2012). English-language creative writing by Chinese university students. English Today. 28 (3): 21-26.

[3] Pimsarn, P. (2013). EFL Students' Writing Apprehension. International Journal of Arts \& Sciences. 6 (4): 99-109.

[4] Shukri, N. (2014). Second language writing culture: issues and challenges from the Saudi Learners' perspective. Arab World English Journal. 5 (3): 190-207.

[5] Darwish, A. S., Sadeqi, A.A. 2016. Reasons for College Students to Plagiarize in EFL Writing: Students' Motivation to Pass. International Education Studies. 9 (9): 99-110.

[6] Zoghipour, E., Nikou, F.R. (2016). theimpact of explicit instruction of lexico-grammatical devices on EFL learners. Modern Journal of Language Teaching Methods ( MJLTM ). 6 (1): 677-690

[7] Hui-Chun, H., \& Young, S. S. (2015). The effectiveness of adopting E-readers to facilitate EFL students' process-based academic writing. Journal of Educational Technology \& Society, 18(1), 250-263. Retrieved from https://search.proquest.com/ docview /1801625114?accountid=25704

[8] Cheng, Y. (2002). Factors associated with foreign language anxiety. Foreign Language Annals, 35(): 647-656

[9] Shang. H. (2013). Factors Associated With English As a Foreign Language University Students Writing Anxiety. International Journal of English Language Teaching. 1 (1): 1-12.

[10] Hossenfour, N., Biria. I.R. (2014). Improving Iranian EFL Learners' Writing through Task-based Collaboration. Theory and Language Practice in Language Studies. 4(11), 2428-2435.

[11] Richards, J.C., Renandya, W.A. (2002). Methodology in Language Teaching: an Anthology of Current Practice. Cambridge: Cambridge University Press

[12] Pazhakh, A. (2007). An investigation on iranian EFL learner' application of avoidance strategies in their writings. Iranian Journal of Language Studies, 1(1), 1-14.

[13] Tran, L.T., (2007). Learners' motivation and identity in the Vietnamese EFL writing classroom. English Teaching: Practice and Critique. 6(1), 151-163

[14] Zhang. H. (2011). A study on ESL writing anxiety among Chinese English majors - Causes , effects and coping strategies for ESL writing anxiety. Retrieved fromwww.diva-portal.org/smash/get/diva2:426646/ FULLTEXT02

[15] Rezaei, M., Jafari, M. (2014). Investigating the Levels, Types, and Causes of Writing Anxiety among Iranian EFL Students: A Mixed Method Design. Procedia - Social and Behavioral Sciences. 98 (): 1545-1554.

[16] Chalagan, M., Rothery, J. (1988). Teaching Factual Writing: Report of the Disadvantagesd Schools Program Litracy Project. Sydney: Metropolitan East Disadvantaged Schools Program.

[17] Christie, F. (1997). Curriculum macrogenres as forms of initiation into a culture. Dalam Christie, F dan J.R. Martin (Ed.), Genre and Institutions: Social processes in the workplace and school, hal. 134-160. London: Continuum.

[18] Johns, A.M. 2002. Introduction. Dalam Johns, A.M. (Ed.), Genre in the Classroom: Multiple Perspectives, hal. 3-16. Marwah, NJ: Lawrence Erlbaum Associates, Inc.

[19] Paltridge, B. (2002). Genre, Text Type, and the English for Academic Purposes (EAP) Classroom. In Ann M. Johns (Ed.), Genre in the Classroom: Multiple Perspectives, pp. 73- 90. Marwah, New Jersey: Lawrence Erlbaum Associates, Publishers.

[20] Rozimela, Y. 2005. Genre- Based Pedagogy for Teaching English Academic Writing in an Indonesian Tertiary Context: A Case Study. Unpublished Disertation. Melbourne: The University of Melbourne.

[21] _.2014. The Students' Genre Awareness and their reading comprehension of different text types. International Journal of Asian Social Science, 4 (4), 460-469.

[22] Tartila, A. Yasin, and Rozimela, Y. 2013. The Implementation of Genre-Based Approach in English Teaching at Islamic Senior High School Model (MAN Model Jambi. Journal of English Language Teaching, 1 (3), pp.1-14.

[23] Nurjamin, A. and L.R., Nurjamin. 2017. The Use of Genre-Based Approach to Teach Students Writing Skill of Hortatory Exposition Text in Bahasa Indonesia. In Proceeedings of CONAPLIN 9. Atlantis Press. Retrieved from https://download.atlantis-press.com, October 10, 2018. 
[24] Fotos, S. 2001. Cognitive Approaches to Grammar Instruction. In Celce-Muricia, M. (Ed.), Teaching English as a Second or Foreign Language $\left(3^{\text {rd }}\right)$, hal. 266-284. Boston, MA: Heinle \& Heinle.

[25] Rozimela, Y. 2006. Penerapan Pendekatan Kognitif dalam Upaya Meningkatkan Kemampuan Grammar dalam TOEFL. Unpublished Research Report. Padang: Universitas Negeri Padang

[26] Richards, J. C. (2001). Curriculum Development in Language Teaching. Cambridge: Cambridge University Press.

[27] DeCarrico, J.S. 2001. Vocabulary Learning and Teaching. In Celce-Muricia, M. (Ed.), Teaching English as a Second or Foreign Language $\left(3^{\mathrm{rd}}\right)$, hal. 285-300. Boston, MA: Heinle \& Heinle.

[28] Larsen-Freeman, D. 2001. Teaching Grammar. In Celce-Muricia, M. (Ed.), Teaching English as a Second or Foreign Language $\left(3^{\text {rd }}\right)$, hal. 251-266. Boston, MA: Heinle \& Heinle.

[29] Little, D. 1991. Learner Autonomy 1: Definitions, Issues and Problems. Dublin: Authentik.

[30] Cotterall, S. 2008. Autonomy and good language learners. In Griffiths, C.(Ed.), Lessons from Good Language Learners, pp. 110-120. Cambridge: Cambridge University Press.

\section{AUTHORS' BIOGRAPHY}

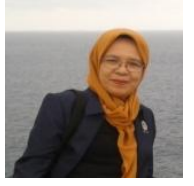

Yenni Rozimela has been teaching EFL at the English Department of Universities Nigeria Padang, Indonesia for more than 30 years. She also often gives trainings and workshops for teachers. Her research interest includes learners' writing development, teaching approaches/ methods, and teacher professional development

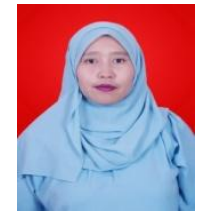

Delvi Wahyuni is a lecturer at the English Department of Universitas Negeri Padang, Indonesia. Her areas of interest deal with learners' writing skills and problems and their grammar mastery and difficulties. Recently she conducted a study on EFL learners' writing anxiety. She is really keen on finding solutions of learners' writing difficulties

Citation: Yenni Rozimela, Delvi Wahyuni. “The Relationship between Students' Perceived Needs, Their Learning Preferences, and Their Ability of Writing an Academic Text" International Journal on Studies in English Language and Literature (IJSELL), vol 7, no. 2, 2019, pp. 1-9. doi: http://dx.doi.org/10.20431/2347 3134.0702001.

Copyright: () 2019 Authors. This is an open-access article distributed under the terms of the Creative Commons Attribution License, which permits unrestricted use, distribution, and reproduction in any medium, provided the original author and source are credited. 